\title{
Helicobacter pylori, food, fish and tilapia
}

\author{
*Cortés-Sánchez, A.D.J. \\ Consejo Nacional de Ciencia y Tecnología (CONACYT). Unidad Nayarit del Centro de Investigaciones \\ Biológicas del Noroeste (UNCIBNOR+). Calle Dos No. 23. Cd. del Conocimiento. Av. Emilio M. González. \\ C.P. 63173. Tepic, Nayarit. México.
}

\begin{abstract}
Article history:
Received: 4 August 2020

Received in revised form: 7

September 2020

Accepted: 9 November 2020

Available Online: 31 January

2021
\end{abstract}

Keywords:

Food safety,

Food pathogens,

Aquaculture,

Antimicrobial resistance

DOI:

https://doi.org/10.26656/fr.2017.5(2).427

\begin{abstract}
Food safety is considered an essential characteristic of food quality and is one that establishes that food, when ingested, will not cause harm to the consumer's health. Foodborne diseases are considered a health problem worldwide due to their incidence and mortality; these diseases have different causal agents of a physical, chemical and biological nature, being the latter mainly related to disease outbreaks where they are included (viruses, bacteria, parasites, and fungi), generally affecting low-income population groups, children, the elderly, pregnant women, and immunosuppressed. This review focused on giving a general description of food-borne diseases, mainly those developed in fish, highly nutritious food that is highly susceptible to deterioration and contamination by various chemical and biological hazards. Among the fish with the highest production for marketing and consumption is tilapia, which can be a vehicle for transmission of various pollutants of biological origin, including Helicobacter pylori, which has been considered an emerging food pathogen with a considerable impact on human health, whose food contamination and infection may be due to different factors such as inadequate hygiene practices at different stages of the food chain, putting the safety of these foods, and/or the health of consumers at risk.
\end{abstract}

\section{Introduction}

Food safety is that characteristic consisting of not causing harm or disease to people who consume it. It is considered, along with the nutritional, organoleptic and commercial characteristics, one of the components of the total quality of food (Fuente-Salcido and BarbozaCorona, 2010). Safety is considered a complex aspect with high impact on social edges such as consumers, governments, the food industry, and academia (Jorquera et al., 2015).

Contamination by physical, chemical and/or biological agents that put food safety at risk can occur at any stage of the food chain, going from primary production to final preparation prior to consumption (from farm to fork), thus generating diseases (FuenteSalcido and Barboza-Corona, 2010; WHO, 2020).

Foodborne illness is considered a public health challenge worldwide due to its incidence and mortality, the socio-economic burden due to high levels of detriment in productivity, costs in health services, implementation, surveillance and control of the food safety (Olea et al., 2012; Alerte et al., 2012; Torrens et al., 2015). These diseases are the product of ingesting food and/or water contaminated with chemical or biological agents in amounts that affect the consumer's health (Torrens et al., 2015; Soto Varela et al., 2016; WHO, 2020).

It is estimated that these diseases affect 1 in 10 people each year worldwide, and generate 420,000 deaths, especially children under 5 years old (WHO, 2020). The general symptoms of these diseases are gastrointestinal, like nausea, vomiting, diarrhea, abdominal pain, and fever; being able to present complications such as sepsis, meningitis, abortions, Reiter's syndrome, Guillan Barré syndrome, cancer, or even death (WHO, 2020). These diseases mainly affect population groups such as children, pregnant women, the elderly, and people with poor immune systems, generally subjected to low socioeconomic levels and high levels of unhealthiness (Olea et al., 2012; WHO, 2020; Soto Varela et al., 2016; Torrens et al., 2015). 
The increase in cases of food-borne illnesses is associated with factors such as market globalization, the introduction of new products and manufacturing processes, changes in society's eating habits, consumption of packaged foods, meals outside the home, sale of meals prepared and fast foods. It is also believed that socio-demographic factors, such as the aging of the population, may contribute to the appearance (Olea et al., 2012; Jorquera et al., 2015).

Contaminants in foods are varied over 250 causative agents of foodborne illness have been described. Contaminants can have a chemical nature (antimicrobials, growth promoters, food additives, natural toxins, disinfectants, heavy metals, pesticides among others), physical nature (fragments of glass, metal, wood, or others) or biological nature (bacteria, parasites, viruses and prions), the latter being mainly bacteria such as Salmonella spp., Clostridium spp., Vibrio spp., Aeromonas hydrofila, Campylobacter jejuni, Helicobacter pylori, Bacillus cereus, Escherichia coli, Staphylococcus aureus, Yersinia enterocolitica, Listeria monocytogenes; those are among the confirmed cases and disease outbreaks (Hernández et al., 2010; Olea et al., 2012; Torrens et al., 2015; Soto Varela et al., 2016).

This review focuses on giving a general description of foodborne illness, particularly fish, highly nutritious food that is highly susceptible to deterioration and contamination by various chemical and biological hazards. Among the fish with the highest production for marketing and consumption is tilapia, which can be a vehicle for transmission of various pollutants of biological origin, including $H$. pylori, which has been considered an emerging food pathogen with a considerable impact on human health, whose food contamination and infection may be due to different factors such as inadequate hygiene practices at different stages of the food chain, putting the safety of these foods and the health of consumers at risk.

\section{Fish}

Fish is all that fish extracted from oceanic or continental waters destined for human or animal consumption (Soares and Gonçalves, 2012). The sources of fish destined for human use and consumption come from fishing and aquaculture activities, reaching in 2016 a combined world production of 170.9 million tons, and a per capita consumption of $20.3 \mathrm{~kg}$ (FAO, 2018). Fish is considered a highly nutritious food (a source of proteins of biological value and digestibility, lipids mainly unsaturated fatty acids, vitamins and minerals) widely marketed and consumed (Soares and Gonçalves, 2012; FAO, 2018).
Due to its chemical composition and slightly acidic $\mathrm{pH}$ of its meat, fish is a food highly susceptible to deterioration derived from the endogenous autolytic activity, microbial and chemical (oxidative) activity, and at the same time, prone to contamination by various physical, chemical and biological agents, due to inadequate hygiene practices throughout the different phases of the food chain, compromising quality and safety and causing a health risk to consumers (Pascual Anderson and Calderon y Pascual, 2000; Soares and Gonçalves, 2012; Ampuero et al., 2018).

Among the dangers and causative agents of diseases due to fish consumption, are those mainly of chemical and biological origin. Table 1 shows the different dangers that compromise safety and put human health through fish at risk.

In the case of microbiological activity and development related to deterioration and contamination of fish associated with human diseases, we will point out that, in captured and alive fish, the microbiota is found in the skin, gills and intestines; the number and type will depend on the time of year, feeding characteristics, geographical area, fish species, capture system and environmental conditions (Huss, 1999; Ramírez et al., 2011). The skin, gills and intestines are organs in direct contact with the muscle, and constitute the beginning of the bacterial invasion, so there will be a proportional correlation between the number of microorganisms in these organs and the muscle in the edible portion (Fuentes et al., 2011). In the case of biological agents, such as the bacteria responsible for the deterioration and causing diseases due to fish consumption, two types are grouped together: a) Autochthonous: those associated with the aquatic environment where they live, such as Pseudomonas spp., Moraxella spp., Shewanella spp., Vibrio spp., Listeria spp., Lactobacillus spp., Clostridium botulinum, Plesiomonas shigelloides, Aeromonas spp., among others where water temperature has a selective effect on its presence, and b) Nonautochthonous bacteria associated with fecal contamination of the aquatic environment and a poor hygiene and sanitation conditions in the different stages of production, processing, distribution and storage, such as Salmonella spp., Shigella spp., Listeria monocytogenes, Escherichia coli, Staphylococcus aureus, among others (Huss, 1997; dos Santos, 2010; Romero-Jarero and Negrete-Redondo, 2011; Ramírez et al., 2011).

\subsection{Tilapia}

Tilapia is a freshwater fish originating in Africa; they belong to the Cichlidae family and are classified 
Table 1. Different pollutants and health hazards transmitted by fish

\begin{tabular}{|c|c|c|c|}
\hline Type / Origin & Classification & Pollutant / Hazard & References \\
\hline \multirow{4}{*}{ Biological } & Parasites & $\begin{array}{l}\text { Members of families: } \\
\text { Opisthorchiidae Heterophyidae } \\
\text { Paragonimidae } \\
\text { Anisakidae } \\
\text { Gnathostomidae Diphyllobothridae } \\
\text { Cryptosporidiidae } \\
\text { Hexamitidae }\end{array}$ & $\begin{array}{l}\text { Huss, (1997); Quijada et al. (2005); dos } \\
\text { Santos (2010); Soares and Gonçalves } \\
\text { (2012); Cortés-Sánchez (2020); Londoñe- } \\
\text { Bailón et al. (2020) }\end{array}$ \\
\hline & Bacteria & $\begin{array}{l}\text { Vibrio parahaemolyticus, } \text {. cholerae, V. } \\
\text { vulnificus, Listeria monocytogenes, } \\
\text { Clostridium botulinum, Clostridium } \\
\text { perfringens, Salmonella spp., Shigella } \\
\text { spp., Streptococcus spp., Escherichia coli, } \\
\text { Staphylococcus aureus, Bacillus cereus, } \\
\text { Campylobacter jejuni, Yersinia } \\
\text { enterocolitica, Aeromonas hydrophila, } \\
\text { Edwarsiella tarda among others. }\end{array}$ & $\begin{array}{l}\text { Huss, (1997); dos Santos (2010); Romero- } \\
\text { Jarero and Negrete-Redondo, (2011); } \\
\text { Cortés et al. (2019); Puig et al. (2019); } \\
\text { Sanabria Sánchez and Chiquillo Pompeyo } \\
\text { (2019); Cortés-Sánchez (2020) }\end{array}$ \\
\hline & Virus & $\begin{array}{l}\text { Virus Hepatitis A, Hepatitis E, } \\
\text { Adenovirus, Norovirus, Astrovirus, } \\
\text { Enterovirus. }\end{array}$ & $\begin{array}{l}\text { Huss, (1997); Soares and Gonçalves } \\
\text { (2012); Cortés-Sánchez (2020) }\end{array}$ \\
\hline & Fungi & $\begin{array}{l}\text { Mycotoxins of genus Claviceps spp., } \\
\text { Fusarium spp., Aspergillus spp., and } \\
\text { Penicillium spp. }\end{array}$ & $\begin{array}{l}\text { Anater et al. (2016); Cortés-Sánchez et al. } \\
\text { (2016); Cortés-Sánchez (2020) }\end{array}$ \\
\hline \multirow{4}{*}{ Chemical } & Biotoxins & $\begin{array}{l}\text { Biogenic amines (Histamine, putrescine } \\
\text { and cadaverine). } \\
\text { Tetrodotoxin, Ciguatera (ciguatoxin, } \\
\text { scaritoxin, maitotoxin, palytoxin and } \\
\text { okadaicacid) gempilotoxin. }\end{array}$ & $\begin{array}{l}\text { Huss, (1997); Izquierdo et al. (2004); dos } \\
\text { Santos (2010); Cortés-Sánchez (2020) }\end{array}$ \\
\hline & Heavy metals & $\begin{array}{l}\text { Lead, cadmium, copper, mercury, arsenic, } \\
\text { selenium, aluminum and strontium }\end{array}$ & $\begin{array}{l}\text { Huss, (1997); Gonzalez et al. (2009); dos } \\
\text { Santos, (2010); Azmat et al. (2012); } \\
\text { Mahalakshmi et al. (2012); Estupiñán and }\end{array}$ \\
\hline & $\begin{array}{l}\text { Organical } \\
\text { Compounds }\end{array}$ & $\begin{array}{l}\text { Antibiotics, hormones, } \\
\text { Polychlorinated biphenyls, polybrominated } \\
\text { diphenyls, polycyclic aromatic }\end{array}$ & $\begin{array}{l}\text { Huss, (1997); dos Santos (2010); Yu et al. } \\
\text { (2011); Cortés-Sánchez (2020) }\end{array}$ \\
\hline & $\begin{array}{l}\text { Pellets or micro } \\
\text {-plastics }\end{array}$ & $\begin{array}{l}\text { Monomers and/or polymers (bisphenol-A, } \\
\text { phthalates, polybrominated diphenyl } \\
\text { ethers, polyethylene, polypropylene, } \\
\text { polystyrene, Polyvinyl Chloride (PVC), } \\
\text { Ethylene-vinyl acetate (EVA) and others }\end{array}$ & $\begin{array}{l}\text { Miranda and de Carvalho-Souza (2016); } \\
\text { Forrest and Hindell (2018); Smith et al. } \\
\text { (2018) }\end{array}$ \\
\hline
\end{tabular}

into three genera that differ from each other according to the patterns of parental care: Tilapia, Orechromis, and Sarotherodon (Jácome et al., 2019). The genus Oreochromis (O. niloticus, O. aureus, O. mossambicus), and interspecific hybrids (red tilapia), have been suitable organisms for aquaculture activities and commercialization worldwide because they tolerate high densities, have a fast growing, are resistant to diseases, are adaptable in captivity, accept balanced diets, in addition to their meat being of acceptable quality and affordable price (Baltazar, 2007; Jácome et al., 2019).

Only in 2016, tilapia (O. niloticus) represented the second place in the total production of fish worldwide, with $8 \%$ being Asian countries like China among the main producers (FAO, 2018). Most of the tilapia, whether captured or cultivated, is consumed fresh, frozen, fillets and/or smoked. In addition, in several tropical and subtropical countries, tilapia is being appreciated as a source of quality animal protein for human consumption, even for its lean and odorless state. It has been proposed as an alternative for the development of ready-to-serve foods such as fish curry, sandwiches, chops, hamburgers, and sticks (Dhanapal et al., 2010). However, tilapia, as a fish destined for human consumption, has been identified as vulnerable to contamination by various biological hazards in specific bacteria such as Aeromonas spp., Pseudomonas spp., Vibrio spp., L. monocytogenes, Staphylococcus aureus, Helicobacter pylori, Escherichia coli, and various genera of the coliform group throughout the food chain that might put consumers' safety and health at risk (Gutiérrez, 2001; Gutiérrez et al., 2010; Fuentes et al., 2011; Ramirez et al., 2011; Fuentes et al., 2011; Goja et al., 
2013; Junior et al., 2014; Abdel-Moein et al., 2015; Eltholth et al., 2018).

\section{Helicobacter pylori}

The Helicobacter genus is extensive, at least thirty species isolated from the gastrointestinal tract of many animals have been identified. Some of the species include $H$. acinonychis, $H$. acinonyx, $H$. bile, $H$. canis, $H$. cetorum, $H$. cholecystus, $H$. felis, $H$. hepaticus, $H$. muridarum, $H$. nemestrinae, $H$. pametensis, $H$. pullorum, $H$. trogontum, $H$. pylori, $H$. cinaedi, $H$. fennelliae, and H. mustalae (Buller, 2004; Romero Cabello, 2007). Helicobacter pylori, from the epidemiological point of view and importance in human health, has a preponderant place, which among its characteristics are: it is a Gram negative bacterium with a spiral or helical shape, measuring 1.5 to $5 \mu \mathrm{m}$ long and 0,3 to $1.0 \mu \mathrm{m}$ in diameter, non-sporulated, microaerophilic (2-5\% oxygen, $\mathrm{CO}_{2} 10 \%$, and $\mathrm{N}_{2} 85 \%$ ), mobile with two to six flagella; it has a genome of $1.6 \mathrm{Mb}$, and an average composition of $\mathrm{G}+\mathrm{C}$ of $39 \%$, it is catalase and positive oxidase, it also produces urease that allows it to tolerate gastric $\mathrm{pH}$ and survive, it is considered a demanding bacterium, since it requires supplemented means for its growth, its growth $\mathrm{pH}$ is $4.5-9$, it is sensitive to environments with low water activity (aw) where growth is inhibited at values $<0.98$ and is inhibited at $\mathrm{NaCl}$ concentrations $\geq 2.5 \mathrm{~g} / \mathrm{L}$, the growth temperature is 34 $40^{\circ} \mathrm{C}$, incubation usually lasts between 3 and 7 days; their colonial morphology is described as small, gray and slightly hemolytic colonies (van Duynhoven and Jonge, 2001; Majalca-Martínez, et al., 2001; Castillo-Rojas et al., 2004; Romero Cabello, 2007; Palomino and Tomé, 2012; Ghorbani et al., 2016; Cervantes-Garcia, 2016; Cervantes, 2016).

The H. pylori infection is considered of importance in aspects of global public health (Fernández-Delgado et al., 2008). H. pylori infection is estimated to affect more than $50 \%$ of the global population depending on their sanitary conditions (Cervantes-Garcia, 2016; Otero, 2017), being the highest prevalence in developing areas such as Africa (79.1\%), Latin America (63.4\%) and Asia (54.7\%), in contrast to the lowest prevalence in North America (37.1\%) and Oceania (24.1\%). Being considered a public health problem (Cervantes, 2016; Otero, 2017), in Latin America, in countries such as Mexico, the prevalence of $H$. pylori infection is $66 \%$ (Paniagua-Contreras et al., 2007).

The infection begins with chronic gastritis that is defined as an infectious disease, which can lead to complications such as peptic ulcer, lymphoma of the lymphoid tissue associated with gastric mucosa (MALT), and gastric cancer; these last two developed in a minority of infected people (1-5\%) (Ramírez and Sánchez, 2008; Atapoor et al., 2014; Cervantes-Garcia, 2016; Cervantes, 2016; Otero, 2017). This microorganism is considered by the World Health Organization (WHO) as a type I carcinogen, and it is associated to $90 \%$ of gastric cancer cases; however, it must be considered that this type of cancer is a multifactorial entity where, in addition to $H$. pylori, requires other factors such as environmental factors (food) or host genetics, among others. Considering that most of those infected cases will not develop cancer, $H$. pylori is treated as a necessary cause, but not sufficient (Ramírez and Sanchez, 2008; Atapoor et al., 2014; Otero, 2017).

One of the main reservoirs of this bacterium is the human stomach, considering that the routes of infection can be oral-oral, fecal-oral, gastro-oral, sexual, and through contaminated food and water (Riveros et al., 2009; Palomino Camargo and Tomé, 2012; Abdel-Moein et al., 2015; Cervantes, 2016; Otero, 2017; Zamani et al., 2017; Bayona and Gutierrez, 2017; Shahi and Yan, 2018). Infection with this bacterium is usually acquired during childhood, associated with socioeconomic status, poor hygienic conditions, and a high degree of overcrowding (Fernández-Delgado et al., 2008; Cervantes, 2016).

The role of water and food in the transmission of $H$. pylori has not been established yet; however, its isolation has been reported in different foods such as dairy, meat, fish, vegetables and salads, especially raw or ready-toeat, indicating that these foods are the source and are involved in the transmission, considering it a food pathogen (Hernández, 2010; Ghorbani et al., 2016; Atapoor et al., 2014; Hemmatinezhad et al., 2016; Zamani et al., 2017; Quaglia and Dambrosio, 2018). This bacterium can exist naturally in aquatic environments such as lakes, rivers, surface and underground drinking water, municipal and wastewater, and coastal marine environments, as a free microorganism or associated with planktonic organisms, being the water both reservoir and transmission source (Palomino Camargo and Tomé, 2012; Fernández-Delgado et al., 2008; Shahi and Yan, 2018). The infective dose in humans from water has been estimated to be $10^{4}-10^{10} \mathrm{CFU} / \mathrm{L}$ (Otero, 2017). H. pylori has the ability to form complex communities between microorganisms attached to surfaces or associated to interfaces, being called biofilms, and it also presents viable but non-cultivable forms (VBNC) where its cellular morphology is coccoid, as for adaptation and survival in conditions of stress due to nutritional situations, and unfavorable physicochemical environment (Palomino Camargo and Tomé, 2012; Giao et al., 2008; Fernández-Delgado et al., 2008; Otero, 2017; Ng et al., 2017; Zamani et al., 2017; 
Bayona and Gutierrez, 2017; Quaglia and Dambrosio, 2018). These VBNC forms have been detected in the oral cavity and feces of the infected, meaning a source of transmission of the pathogen (Juneja and Sofos, 2010).

The pathogenicity and virulence mechanisms of this bacterium are varied. Among those, it can be found that they are structural lipopolysaccharides; the spirillated structure and flagella for interaction, mobility in gastric tissue, adhesins for colonization and tropism in gastric tissue, such as Lewis B antigens (BabA), inflammatory outer membrane protein (OipA), sialic acid binding adhesin (SabA), adhesion-associated lipoprotein (AlpA and AlpB), and HopZ, which prevent it from being carried away by peristalsis, ciliary activity, and epithelial turnover enzymes such as urease that transforms urea into ammonia, giving rise to an alkaline microenvironment and protecting it against gastric acidity, lipases, and proteases that contribute to the degradation of gastric mucus and loss of hydrophobicity of the mucosa, decreasing the ability of mucous cells to secrete mucus, catalase, and superoxide dismutase that protect the bacteria from oxidative processes of immune cells (Macro phages and neutrophils), in addition to phospholipase A2, phospholipase $\mathrm{C}$, mucinase, alkaline and acid phosphatase (Dunn, 1997; Posse et al., 2006; González López and Rodríguez González, 2011; Espinoza, 2012; Cervantes-Garcia, 2016). Different virulence factors of $H$. pylori have also been described, among which are vacuolizing cytoxin encoded in the vacA gene (vacuolization associated gene) that varies in regions $\mathrm{s}$ and $\mathrm{m}$, having $\mathrm{s} 1$ or $\mathrm{s} 2$ and $\mathrm{m} 1$ or $\mathrm{m} 2$ allelic types. This gene is present in all strains of $H$. pylori associated with damage to epithelial cells in the gastric tract and the cagA protein that may be involved in the activation of the vacuolizing toxin, and is encoded in the cagA gene (cytotoxin associated gene) present in 50\%$70 \%$ of strains associated with peptic ulceration and gastric cancer (Castillo-Rojas et al., 2004; PaniaguaContreras et al., 2007; Cervantes-Garcia, 2016; Ghorbani et al., 2016; Morales et al., 2018).

\subsection{Prevention and control of food contamination and $H$. pylori infection}

Among the main risk factors for $H$. pylori infection, it has been related to low educational level, low level of sanitation and hygiene, low health care, infected family members, low socioeconomic status, overcrowding, access to low-quality water sanitation, inadequate hygiene management and food contamination (van Duynhoven and Jonge, 2001; Zamani et al., 2017; Bayona and Gutiérrez, 2017). H. pylori infection can be considered a zoonosis due to its detection in the oral and gastric cavity of animals in contact with humans such as dogs, cats, cows and pigs, and its possible transmission is considered by the aforementioned animals (Palomino Camargo and Tomé, 2012; Bayona and Gutiérrez, 2017). Studies conducted on foods of aquatic origin, usually consumed minimally processed such as shellfish in PinaPérez et al. (2019), reported the detection of $H$. pylori in samples of shellfish (mussels, clams and cockles) from the Spanish west coast, confirming the possible relationship between the presence of $H$. pylori in contaminated seawater, and shellfish as vehicles for entry of the pathogen into the food chain and a risk to public health. Meanwhile, in fish such as tilapia, AbdelMoein et al. (2015) detected the presence of H. pylori in both cultured specimens and in wild specimens captured from different aquatic environments, considering it a source of H. pylori transmission, and indicating that the fish may be a potential reservoir and transmitter of zoonosis. However, it also states that more studies of the pathogen occurrence in other fish are necessary.

In foods of meat origin with a high aw, $\mathrm{pH}$, and optimal salt content, in addition to the presence of amino acids such as arginine, histidine, isoleucine, leucine, methionine, phenylalanine, alanine, valine, proline, serine, and tryptophan, the growth and presence of $H$. pylori is promoted, in addition to the fact that in temperatures below $30^{\circ} \mathrm{C}$ the bacterium can survive in fresh vegetables, fresh meats, and dairy products for several days, making it a source of transmission (van Duynhoven and Jonge, 2001; Palomino Camargo and Tomé, 2012; Ghorbani et al., 2016; Zamani et al., 2017; $\mathrm{Ng}$ et al., 2017; Bayona and Gutierrez, 2017).

Another factor in the control and prevention of food contamination by H. pylori is the microbiological quality of the water. Drinking water and food production water must be subjected to adequate disinfection processes that eliminate the possibility of $H$. pylori transmission (Shahi and Yan, 2018). It has been reported that H. pylori in chlorine and ozone disinfection processes are more resistant than E. coli and C. jejuni. Therefore, inadequate disinfection conditions, such as the concentration of the disinfectant and the time of exposure, contribute to the persistence of the pathogen in the water and transmission in its cellular state, which can be in forms either spiral or coccoid (VBNC) (Johnson et al., 1997; Baker et al., 2002; Percival and Thomas, 2009; Orta de Velázquez et al., 2016). In the United States, water service companies supply median residual chlorine of $1.1 \mathrm{mg} / \mathrm{L}$, and an average exposure time of 45 minutes until the first use in the distribution system; this level of chlorination can be considered adequate to inactivate H. pylori (Johnson et al., 1997).

In foodborne illnesses, fish has been related to 
disease outbreaks, being the causal factors biological agents such as bacteria, where contamination due to lack or inadequate hygiene control at different stages of the food chain, such as production, transport, warehouse, handling, and processing are among the contributing factors (OMS, 2007; Ramírez et al., 2011; Alerte et al., 2012; Espinosa et al., 2014; Soares and Gonçalves, 2012; OMS,2016). Poor practices and hygiene conditions in food production, considering water and human reservoirs of $\mathrm{H}$. pylori, favor contamination during food handling, preparation and the health risk (Palomino Camargo and Tomé, 2012; Atapoor et al., 2014; Ghorbani et al., 2016; Hemmatinezhad et al., 2016; Shahi and Yan, 2018). Therefore, it has been stipulated that food safety standards that allow the safe production of products such as good agricultural practices, Good Aquaculture Practices for Fish Farming (GAP-FF), Good Manufacturing Practices (GMP), must be implemented in the production of food, as well as Sanitation Standard Operating Procedures (SSOP) and Hazard Analysis and Critical Control Points (HACCP) systems in the different phases of the food chain, and food hygiene education for final preparers or handlers (OMS, 2007; Ramirez et al., 2011; Atapoor et al., 2014; Jorquera et al., 2015; Ghorbani et al., 2016; Hemmatinezhad et al., 2016; OMS, 2016).

\subsection{Microbiological analysis of food}

Conventional microbiological methods for pathogenic bacteria generally involve a laborious and time-consuming process in the proper use of enrichment culture media, and selective for subsequent biochemical, morphological and/or serological confirmation; in addition to that the target microorganism may present a viable but non-cultivable state (VBNC), which prevents or hinders the use of culture methods as a detection tool (Palomino-Camargo and González-Muñoz, 2014). Isolation and detection of $H$. pylori is difficult and infrequent, with recovery rates between $30-73 \%$ by conventional methods due to morphological changes of this bacterium due to not having conditions similar to the gastric epithelium that favor its colonization and growth, presenting a VBNC state, and the overgrowth or competition of other accompanying microorganisms (Fernández-Delgado et al., 2008; Riveros et al., 2009; Palomino Camargo and Tomé, 2012; Bernal and Cadavid Hincapié, 2013; Quaglia and Dambrosio, 2018).

Multiple investigations have been reported in the culture of this microorganism from various types of samples using different enrichment culture media, selective and differential such as agar and/or broth as Wilkins Chalgren agar, Brucella agar, Müeller Hinton agar, Brain Heart Infusion broth, Agar Skirrow,
Columbia Agar, and Soy broth trypticase applying in turn some of the different supplements (serum or horse blood, sheep blood, fetal bovine serum, yeast extract, lysed human erythrocytes, hemin, cyclodextrin, cholesterol, starch and/or nicotinamide adenine), antibiotics (trimethoprim, cycloheximide, vancomycin, nalidixic acid, colistin methanesulfonate, cefsulodin and/ or amphotericin B) that favor the growth of the bacteria, and the use of different microaerophilic conditions, temperature between $35-37^{\circ} \mathrm{C}$, with a time of incubation for 5 to 10 days, where the developed colonies are small grayish and shiny, are $1 \mathrm{~mm}$ in diameter, and are subsequently tested biochemical identification such as Gram staining, urease, cytochrome oxidase and catalase (Bode et al., 1993; Majalca-Martínez et al., 2001; Lu et al., 2002; Buller, 2004; Fernández-Delgado et al., 2008; Bermúdez et al., 2009; Espinoza, 2012; Atapoor et al., 2014; Mousavi and Dehkordi, 2014; Ghorbani et al., 2016; Cervantes, 2016; Saeidi and Sheikhshahrokh, 2016; Quaglia and Dambrosio, 2018).

The difficulties presented by traditional cultivation techniques in recovering pathogenic microorganisms from the environment or food samples means that techniques such as Polymerase Chain Reaction (PCR), Fluorescence In Situ Hybridization (FISH), and immunofluorescence have been well established as an alternative for the detection of pathogens such as $H$. pylori (Fernández-Delgado et al., 2008; Mousavi and Dehkordi, 2014; Atapoor et al., 2014; FloresEncarnación et al., 2015; Ghorbani et al., 2016; Cervantes, 2016; Quaglia and Dambrosio, 2018).

Detection through PCR in clinical, water and food samples is made by detecting genes that encode virulence factors such as cytotoxin (vacA), cagA gene, the ureA gene that encodes the A subunit of the urease enzyme, glm $M$ gene coding for a phosphoglucosamine mutase, oipA gene involved in colonization of mucosa, and highly conserved sequences of the gene that codes for ribonucleic acid of the $16 \mathrm{~S}$ subunit of the ribosome (16S rRNA), have shown good values of sensitivity and specificity in use (Lu et al., 2002; Paniagua-Contreras et al., 2007; Meng et al., 2008; Bermúdez et al., 2009; Mousavi and Dehkordi, 2014; Ghorbani et al., 2016; Saeidi and Sheikhshahrokh, 2016; Hemmatinezhad et al., 2016).

\subsection{Antimicrobial resistance}

Antimicrobial resistance is considered a major threat and challenge to human and animal health worldwide (Puig Peña et al., 2019; FAO/WHO, 2020). Antimicrobial resistance is defined, from a clinical perspective, as the disappearance of response and a failure in the treatment of the disease to eliminate the 
causative agent before the administration of antimicrobials, increasing morbidity, mortality and cost of medical care (Garcia et al., 2014; Puig Peña et al., 2019). In the field of food, these intervene in the development and spread of antimicrobial resistance, having an impact on food safety and food security; the presence of antimicrobial resistant microorganisms in the food chain is a potential route of exposure and transfer to humans (Puig Peña et al., 2011; FAO/WHO, 2020).

It has been established that the factors related to the generation of this problem are due to a combination of various factors, such as the inappropriate use of antimicrobials in humans and animals, counting the latter with three functions: therapeutics, prophylaxis and growth promotion aimed at the production of food (Puig Peña et al., 2011).

Microorganisms, including bacteria, acquire antimicrobial resistance capacity through different mechanisms such as the modification of membrane permeability, the extraction by pumping mechanisms, enzymatic inhibition, modification of the attack target, or an alteration of the composition of the cell wall (Tafur et al., 2008; Puig Peña et al., 2011, García Castellanos et al., 2014)

The microorganisms are capable of transferring and exchanging genetic material (plasmids, insertion sequences, integrons, and transposons), allowing genetic recombination, through transformation, transduction, or conjugation (Sánchez-B et al., 2012). Therefore, developing different resistance mechanisms, and increasing the spread of this phenomenon (Puig Peña et al., 2011). In the case of food from aquatic environments such as aquaculture, they are a means for microorganisms, including pathogens, to exchange resistance genetic material, constituting a risk for human and animal health (Puig Peña et al., 2019).

Food-borne disease-causing bacteria have already been reported in various studies to show resistance to different antimicrobials, including Escherichia coli, Listeria monocytogenes, $V$. cholerae, $H$. pylori, Staphylococcus spp., Campylobacter spp., Aeromonas spp., among others (Puig Peña et al., 2011; De Oliveira et al., 2013; Hemmatinezhad, 2016; Cáceres et al., 2017; Puig Peña et al., 2019).

Treatments for $H$. pylori infection are: acidsuppressing drugs (proton pump inhibitors or $\mathrm{H} 2$ receptor antagonists) such as bismuth salts, ranitidine, omeprazole, and antimicrobials such as amoxicillin, macrolides (clarithromycin), tetracycline, and nitroimidazole (metronidazole) (Posse et al., 2004; Gerrits et al., 2006; Romero Cabello, 2007; Hernández,
2008; Cervantes, 2016). Due to the serious consequences of an $H$. pylori infection, it must be detected and eliminated. However, there is a challenge in its elimination because the schemes for this purpose are less effective due to resistance of the microorganism to specifically clarithromycin antibiotics, so the World Health Organization (WHO) has included this pathogen among those that threaten humanity and that urgently merit measures for its control (Riveros et al., 2009; Cervantes, 2016; Otero, 2017). Levofloxacin and ciprofloxacin are frequently used in second-line treatment; however, studies have been reported that strains resistant to these antibiotics have appeared (Gerrits et al., 2006; Hernández et al., 2008; Cervantes, 2016). Resistance to amoxicillin and nitroimidazole such as metronidazole is also common and high, reducing the response to treatment, which requires adjusting dose and duration (Gerrits et al., 2006; Figueroa et al., 2012; Cervantes, 2016).

The H. pylori resistance to different drugs used in the treatment of infection has been reported by different mechanisms, where they show that, for metronidazole, it is through mutations in the $r d x A$ and frx $A$ genes making them dysfunctional, and which encode NADPH-nitro reductase and NADPH-flavin oxide reductase respectively, avoiding drug activation (Hernández et al., 2008). For amoxicillin, the resistance mechanism is mutations in the antimicrobial binding proteins causing changes in the amino acid sequence and conformations in reducing the affinity. Meanwhile, for tetracyclines, the resistance mechanism is due to mutations in the $16 \mathrm{~S}$ rrn gene that codes for the $16 \mathrm{~S}$ ribosomal RNA of the $30 \mathrm{~S}$ subunit of the microbial ribosome, blocking the inhibition of protein synthesis by the drug. In addition, other mechanisms have been proposed, for example, the efflux or expulsion protein activity and reduced membrane permeability. Clarithromycin inhibits protein synthesis and the resistance mechanism is the result of point mutations in the $23 \mathrm{~S}$ rrn gene that codes for the $23 \mathrm{~S}$ rRNA of the $50 \mathrm{~S}$ ribosomal subunit through substitutions of nitrogenous bases, leading to modifications in the structure of the ribosome, and affecting the binding of the antibiotic and, therefore, protein synthesis is not altered (Hernández et al., 2008). And for levofloxacin, and ciprofloxacin that inhibits DNA replication by binding to DNA gyrase, the resistance mechanism is the mutation of the DNA gyrase subunit A (gyr A), replacing aspartate with glycine (D91G) and asparagine with lysine (N87K) (Hernández et al., 2008).

In studies involved in the isolation of $H$. pylori, and in strains resistant to antimicrobials from foods such as those ready to eat ones (salads and soups), authors such 
as Hemmatinezhad et al. (2016) have reported the analysis of 550 samples, where contamination by $H$. pylori occurred in $13.45 \%$ of those, and the isolated strains had high levels of resistance to antimicrobials such as amoxicillin (94.59\%), ampicillin (93.24\%), metronidazole (89.18\%) and tetracycline (72.97\%). Yahaghi et al. 2014 detected, in 380 samples of vegetables (radish, basil, parsley, spinach, lettuce, corn, broccoli, cucumber, among others) and 50 salads collected from supermarkets and grocery stores in Iran, the presence of $H$. pylori in $13.68 \%$ and $14 \%$, respectively, of samples and the isolated strains presented high levels of antibiotic resistance against metronidazole (77.96\%), amoxicillin $(67.79 \%)$ and ampicillin (61.01\%). However, they are sensitive to levofloxacin, rifampin, trimethoprim, cefsulodin, and spiramycin.

Mousavi and Dehkordi (2014) conducted studies on antimicrobial resistance on $H$. pylori strains isolated from raw milk samples and dairy products (cheese, cream, and ice cream) marketed in Iran, reporting high levels of contamination by this pathogen, (19.5\%) and levels of resistance to ampicillin (84.4\%), tetracycline (76.6\%), erythromycin (70.5\%) and metronidazole $(70 \%)$. In all previous investigations, the authors conclude that in the detected strains there is high resistance to antimicrobials used in the treatment for infection of this pathogen, in addition to the fact that the consumption of contaminated food can constitute a potential health risk, in particular, due to the consumption of foods are mainly raw or produced under inadequate hygiene practices, which is why they suggest sanitary surveillance in food production (Mousavi and Dehkordi, 2014; Yahaghi et al., 2014; Hemmatinezhad et al., 2016). Among the measures implemented to face antimicrobial resistance is through the application of hygiene systems and procedures all along with the food production and supply chain (Puig Peña et al., 2011; FAO/WHO, 2020). Control of antimicrobial resistance in food should be implemented in bacteria that indicate sanitary quality as hygiene parameters in addition to pathogens and zoonoses (Puig Peña et al., 2011).

\section{Conclusion}

Fish is considered a highly nutritious food, the main source of protein, produced through fishing and aquaculture activities for worldwide distribution and commercialization. Among the main fish producing species is tilapia (O. niloticus) due to its favorable aquaculture production conditions and market acceptance. However, fish as food is not only nutritious but also susceptible to deterioration and contamination by various biological hazards, mainly bacteria, such as $E$. coli, Salmonella spp., Vibrio spp., Listeria spp., among others that are frequently related with the cause of gastrointestinal diseases in humans, mainly due to the fact that they are subjected to poor conditions and hygiene practices in their production and conservation.

H. pylori in recent years have gained relevance in the context of public health due to its high incidence, impact and resistance to antimicrobials. $H$. pylori affect a large part of the world's population and can be transmitted through the consumption of contaminated food and water such as fish. As the pathogen is detected in water, animals and humans make them a source of transmission, so it is necessary to monitor and control hygiene conditions in the production, conservation and handling of food throughout of the entire food chain in order to avoid various biological hazards including $H$. pylori to ensure the safety of food available for human consumption.

\section{References}

Abdel-Moein, K.A., Saeed H. and Samir, A. (2015). Novel detection of Helicobacter pylori in fish: A possible public health concern. Acta Tropica, 152, 141-144. https://doi.org/10.1016/

j.actatropica.2015.09.005

Alerte, V., Cortés, A.S., Díaz, T.J., Vollaire, Z.J., Espinoza, M.M.E., Solari, G.V., Cerda, L.J. and Torres. H.M. (2012). Foodborne disease outbreaks around the urban Chilean areas from 2005 to 2010. Revista Chilena de Infectología, 29(1), 26-31. https://doi.org/10.4067/S0716-10182012000100004

Ampuero, J.M.V., Alcántara, W.R.T., Talenas, M.Á.C. and Sotil, S.A. (2018). Microbiological evaluation of fish and seafood available in Huánuco's markets. Investigación Valdizana, 12(2), 75-82. https:// doi.org/10.33554/riv.12.2.142

Anater, A., Manyes, L., Meca, G., Ferrer, E., Luciano, F.B., Pimpão, C.T. and Font, G. (2016). Mycotoxins and their consequences in aquaculture: $\mathrm{A}$ review. Aquaculture, 451, 1-10. https:// doi.org/10.1016/j.aquaculture.2015.08.022

Atapoor, S., Dehkordi, F.S. and Rahimi, E. (2014). Detection of Helicobacter pylori in various types of vegetables and salads. Jundishapur Journal of Microbiology, 7(5), e10013. https://doi.org/10.5812/ jjm. 10013

Azmat, H., Javed, M. and Jabeen, G. (2012). Acute toxicity of aluminium to the fish (Catla catla, Labeo rohita and Cirrhina mrigala). Pakistan Veterinary Journal, 32(1), 85-87.

Baker, K.H., Hegarty, J.P., Redmond, B., Reed, N.A. and 
Herson, D.S. (2002). Effect of oxidizing disinfectants (chlorine, monochloramine and ozone) on Helicobacter pylori. Applied and Environmental Microbiology, 68(2), 981-984. https:// doi.org/10.1128/AEM.68.2.981-984.2002

Baltazar, P.M. (2007). Tilapia in Peru: aquiculture, market and perspectives. Revista Peruana de Biología, 13(3), 267-273. https://doi.org/10.15381/ rpb.v13i3.2355

Bayona Rojas, M.A. and Gutiérrez Escobar, A.J. (2017). Helicobacter pylori: transmission routes. Medicina, 39(3), 210-220.

Bermúdez Díaz, L., Ernesto Torres Domínguez, L. and Rodríguez González, B.L. (2009). Techniques used for the Helicobacter pylori infection detection. Revista Cubana de Medicina, 48(1), 1-14.

Bernal López, S. and Cadavid Hincapié, T.C. (2013). Estrategias de cultivo de Helicobacter pylori en aguas residuales. Trabajo de grado. Presentado como requisito parcial para optar por el título de Bacteriólogo(a). Bogotá D.C., Colombia: Pontificia universidad javeriana. Thesis. [In Spanish].

Bode, G., Mauch, F. and Malfertheiner, P. (1993). The coccoid forms of Helicobacter pylori. Criteria for their viability. Epidemiology and Infection, 111(3), 483-490. https://doi.org/10.1017/ S0950268800057216

Buller, N.B. (2004). Bacteria from fish and other aquatic animals: a practical identification manual. USA: CABI Publishing. https:// doi.org/10.1079/9780851997384.0000

Cáceres, E.X.U., Becerra, A.M.A. and Bernal, C.P.J. (2017). Determinación del perfil de susceptibilidad a antibióticos de Listeria sp., aisladas de leche cruda de vaca en Tunja. Revista Investigación en Salud Universidad de Boyacá, 4(1), 38-52. [In Spanish]. https://doi.org/10.24267/23897325.195

Castillo-Rojas, G., Mazarí-Hiriart, M. and López-Vidal, Y. (2004). Helicobacter pylori: Focus on CagA and VacA major virulence factors. Salud pública de México, 46(6), 538-548. https://doi.org/10.1590/ S0036-36342004000600010

Cervantes-García, E. (2016). Helicobacter pylori: mecanismos de patogenicidad. Revista Latinoamericana de Patología Clínica y Medicina de Laboratorio, 63(2), 100-109. [In Spanish].

Cervantes García, E. (2016). Diagnóstico y tratamiento de infecciones causadas por Helicobacter pylori. Revista Latinoamericana de Patología Clínica y Medicina de Laboratorio, 63(4), 179-189. [In Spanish].

Cortés Sánchez, A.D.J., Díaz Ramírez, M., Rayas Amor,
A., Cruz Monterrosa, R.G., Jiménez Guzmán, J. and Salgado Cruz, M. (2019). Edwardsiella tarda Ewing y McWhorter 1965: food and fish. Agroproductividad, 12(11), 55-60. [In Spanish]. https://doi.org/10.32854/agrop.vi0.1501

Cortés-Sánchez, A.D.J., San Martin-Azocar, A.L., García-Barrientos, R. (2016). About Fungi, Mycotoxins and Food Safety. IOSR Journal of Environmental Science, Toxicology and Food Technology, 10(12), 99-109.

Cortés-Sánchez, A.D.J. (2020). Food, Fish and Diseases Transmitted to the Consumer. Journal of Advanced Laboratory Research in Biology, 11(2), 16-23.

De Oliveira Luna, R., Bezerra, S.S., Carvalho, J.N., Pereira, F.C., Barretto, A.C.G., Galvão, S.M.R. and Mendes, E.S. (2013). Identificação molecular e perfil de resistência a antimicrobianos de Aeromonas spp. isoladas de queijo de coalho tipo a. Brazilian Journal of Veterinary Medicine, 35(3), 205-211. [In Spanish].

Dhanapal, K., Reddy, G.V.S., Nayak, B.B., Basu, S., Shashidhar, K., Venkateshwarlu, G. and Chouksey, M.K. (2010). Quality of ready to serve tilapia fish curry with PUFA in retortable pouches. Journal of Food Science, 75(7), S348-S354. https:// doi.org/10.1111/j.1750-3841.2010.01762.x

dos Santos, C.A.M.L. (2010). Doenças transmitidas por pescado no Brasil. Brazilian Journal of Veterinary Medicine, 32(4), 234-241. [In Spanish].

Dunn, B.E., Cohen, H. and Blaser, M.J. (1997). Helicobacter pylori. Clinical Microbiology Reviews, 10(4), 720-741. https://doi.org/10.1128/ CMR.10.4.720

Eltholth, M., Fornace, K., Grace, D., Rushton, J. and Häsler, B. (2018). Assessing the chemical and microbiological quality of farmed tilapia in Egyptian fresh fish markets. Global Food Security, 17, 14-20. https://doi.org/10.1016/j.gfs.2018.03.003

González Weller D., Gutiérrez A., Rubio C., Hernández C. and Hardisson A. (2009). Niveles de aluminio y estroncio en los seis grupos de alimentos más consumidos por la población canaria. Revista de Toxicologia, 26, 30-32. [In Spanish].

Espinosa, L., Varela, C., Martínez, E.V. and Cano, R. (2015). Brotes de enfermedades transmitidas por alimentos. España, 2008-2011 (excluye brotes hídricos). Boletín Epidemiológico Semanal, 22(11), 130-136. [In Spanish].

Espinoza Mata, A. (2012). Detección molecular de Helicobacter pylori en agua y. México: Universidad Autónoma de Nuevo León, PhD Dissertation. [In Spanish]. 
Estupiñán, E.J.V. and Africano, P.E.R. (2015). Mercury, lead and copper in Orechromis niloticus tissues: upstream area of the Chicamocha river, Volcán village, Paipa, Colombia. Producción + Limpia, 10 (2), 114-126. [In Spanish]. https://doi.org/10.22507/ pml.v10n2a10

FAO (2018). El estado mundial de la pesca y la acuicultura 2018. Cumplir los objetivos de desarrollo sostenible. Organización mundial para la agricultura y alimentación (FAO). Roma: FAO. [In Spanish]. Retrieved from FAO website: http://www.fao.org/3/ i9540es/i9540es.pdf

FAO/WHO, (2020). Resistencia a los antimicrobianos. Organización mundial de la salud. Organización mundial para la agricultura y alimentación. Codex Alimentariux. Retrieved from FAO website: http:// www.fao.org/fao-who-codexalimentarius/thematicareas/antimicrobial-resistance/en/ [In Spanish].

Fernández-Delgado, M., Contreras, M., García-Amado, M.A., Michelangeli, F. and Suárez, P. (2008). Evidencias de la transmisión acuática de Helicobacter pylori. Interciencia, 33(6), 412-417. [In Spanish].

Figueroa, M., Cortés, A., Pazos, Á. and Bravo, L.E. (2012). Sensibilidad in vitro a amoxicilina $y$ claritromicina de Helicobacter pylori obtenido de biopsias gástricas de pacientes en zona de bajo riesgo para cáncer gástrico. Biomédica: Revista del Instituto Nacional de Salud, 32(1),32-42. [In Spanish].

Flores-Encarnación, M., Nava-Nolazco, R.M., AguilarGutiérrez, G.R., González-Gutiérrez, J.Y., HerreraRomero, A.U. and Cabrera-Maldonado, C. (2015). The coccoid forms of Helicobacter pylori: A permanence mechanism. Basic Research Journal of Medicine and Clinical Sciences BRJMCS, 4(2), 5054.

Forrest, A.K. and Hindell, M. (2018). Ingestion of plastic by fish destined for human consumption in remote South Pacific Islands. Australian Journal of Maritime and Ocean Affairs, 10(2), 81-97. https:// doi.org/10.1080/18366503.2018.1460945

Fuente-Salcido, N.M.D.L. and Barboza-Corona, J.E. (2010). Inocuidad y bioconservación de alimentos. Acta Universitaria, 20(1), 43-52. [In Spanish]. https://doi.org/10.15174/au.2010.76

García Castellanos, T., Castillo Marshal, A. and Salazar Rodríguez, D. (2014). Mechanisms of resistance to beta-lactams in Gram-negative bacteria. Revista Cubana de Salud Pública, 40(1), 129-135.

Gerrits, M.M., van Vliet, A.H., Kuipers, E.J. and Kusters, J.G. (2006). Helicobacter pylori and antimicrobial resistance: molecular mechanisms and clinical implications. The Lancet Infectious Diseases, 6(11), 699-709. https://doi.org/10.1016/S1473-3099 (06)70627-2

Ghorbani, F., Gheisari, E. and Dehkordi, F.S. (2016). Genotyping of vacA alleles of Helicobacter pylori strains recovered from some Iranian food items. Tropical Journal of Pharmaceutical Research, 15(8), 1631-1636. https://doi.org/10.4314/tjpr.v15i8.5

Giao, M.S., Azevedo, N.F., Wilks, S.A., Vieira, M.J. and Keevil, C.W. (2008). Persistence of Helicobacter pylori in heterotrophic drinking-water biofilms. Applied and Environmental Microbiology, 74(19), 5898-5904. https://doi.org/10.1128/AEM.00827-08

Goja, A.M. (2013). Microbiological assessment of three types of fresh fish (Tilapia niloticus, Labeo niloticus and Hydrocynus spp.) sold in Ed Dueim, Sudan. New York Science Journal, 6(4), 49-54.

González López, L. and Rodríguez González, B.L. (2011). Pathogenesis of infection due to Helicobacter pylori. Revista Cubana de Medicina, 50(4), 441-452.

Gutiérrez, K., Alfaro, M., Granados, F., Sánchez, J., García, F. and Rodríguez, C. (2010). Detección de tetraciclinas en nueve lotes de alimentos para cerdos, tilapias y pollos producidos en Costa Rica: incumplimiento de normativas y disconformidades con el etiquetado oficial de garantía. Agronomía Costarricense, 34(2), 145-151. [In Spanish]. https:// doi.org/10.15517/rac.v34i2.3628

Gutiérrez, M.A.G. (2001). Niveles de concentración de mercurio total en tilapia en los sitios de pesca de las comunidades pesqueras del lago XoIotlán. Revista Encuentro de la Universidad Centroamericana, 33 (58), 91-102. [In Spanish]. https://doi.org/10.5377/ encuentro.v0i58.4118

Hemmatinezhad, B., Momtaz, H. and Rahimi, E. (2016). VacA, cagA, iceA and oipA genotypes status and antimicrobial resistance properties of Helicobacter pylori isolated from various types of ready to eat foods. Annals of Clinical Microbiology and Antimicrobials, 15, 2. https://doi.org/10.1186/s12941 $-015-0115-\mathrm{z}$

Hernández Cruza, P.E. (2010). Bacterias patógenas emergentes transmisibles por los alimentos presented at the Monografías de la Real Academia Nacional de Farmacia, p. 147-179. Spain: Real Academia Nacional de Farmacia. [In Spanish].

Hernández Power, M., Reyes Zamora, O. and Rodríguez González, B.L. (2008). The resistance to antibiotics in Helicobacter pylori. Revista Cubana de Medicina, 47(4). [In Spanish]. http://scielo.sld.cu/scielo.php? script $=$ sci_arttext\&pid=S0034$75232008000400009 \& \operatorname{lng}=$ es\&tlng=en. 
Huss, H.H. (1997). Aseguramiento de la calidad de los productos pesqueros. Laboratorio Tecnológico. Ministerio de Pesca. Dinamarca. Organización de las Naciones Unidas para la Agricultura y la Alimentación Roma: FAO. [In Spanish]. Retrieved from T1768S00.htm\#TOC

Huss, H.H. (1999). El Pescado Fresco: Su Calidad y Cambios de su Calidad. FAO Documento técnico de pesca 348. Organización de las Naciones Unidas para la Agricultura y la Alimentación (FAO). Laboratorio Tecnológico. Ministerio de Pesca. Dinamarca. [In Spanish]. Retrieved from http:// www.fao.org/3/v7180s/v7180s00.htm\#Contents

Izquierdo, P., Sandrea, L., Allara, M., González, P., García, A. and Valecillos, Y. (2004). Bacteriological Evaluation and Histamine Content in Minced Precooked Fish in Venezuela. Revista Científica, 14(5), 467-473.

Jácome, J., Quezada A.C., Sánchez Romero, O., Pérez, J.E. and Nirchio, M. (2019). Tilapia in Ecuador: paradox between aquaculture production and the protection of Ecuadorian biodiversity. Revista Peruana de Biologia, 26(4), 543-550. https:// doi.org/10.15381/rpb.v26i4.16343

Johnson, C.H., Rice, E.W. and Reasoner, D.J. (1997). Inactivation of Helicobacter pylori by chlorination. Applied and Environmental Microbiology, 63(12), 4969-4970.

AEM.63.12.4969-4970.1997

Jorquera, D., Galarce, N. and Borie, C. (2015). The challenge of controlling foodborne diseases: bacteriophages as a new biotechnological tool. Revista Chilena de Infectología, 32(6), 678-688. https://doi.org/10.4067/S0716-10182015000700010

Juneja, V.K. and Sofos, J.N. (2010). Pathogens and toxins in foods. USA: ASM Press. https:// doi.org/10.1128/9781555815936

Junior, P.G., Assunção, A.W., Baldin, J.C. and Amaral, L.A. (2014). Microbiological quality of whole and filleted shelf-tilapia. Aquaculture, 433, 196-200. https://doi.org/10.1016/j.aquaculture.2014.06.015

Londoñe-Bailón, P., Céspedes-Chombo, R. and Díaz Pereyra, K. (2020). Evaluation of the presence of Adenocephalus pacificus in fish of greater consumption in Peru in the period 20162017. Revista de Investigaciones Veterinarias del Perú, 31(1), e17552. https://doi.org/10.15381/ rivep.v31i1.17552

Lu, Y., Redlinger, T.E., Avitia, R., Galindo, A. and Goodman, K. (2002). Isolation and genotyping of Helicobacter pylori from untreated municipal wastewater. Applied and Environmental Microbiology, 68(3), 1436-1439. https:// doi.org/10.1128/AEM.68.3.1436-1439.2002

Mahalakshmi, M., Balakrishnan, S., Indira, K. and Srinivasan, M. (2012). Characteristic levels of heavy metals in canned tuna fish. Journal of Toxicology and Environmental Health Sciences, 4(2), 43-45. https://doi.org/10.5897/JTEHS11.079

Majalca-Martínez, C., Rivera-Cabrera, J., Ochoa-Pérez, S.A. and Giono-Cerezo, S. (2001). Transporte, aislamiento, identificación y conservación de cepas de Helicobacter pylori. Bioquimia, 26(4), 85-89. [In Spanish].

Meng, X., Zhang, H., Law, J., Tsang, R. and Tsang, T. (2008). Detection of Helicobacter pylori from food sources by a novel multiplex PCR assay. Journal of Food Safety, 28(4), 609-619. https:// doi.org/10.1111/j.1745-4565.2008.00135.x

Miranda, D.D.A. and de Carvalho-Souza, G.F. (2016). Are we eating plastic-ingesting fish? Marine Pollution Bulletin, 103(1-2), 109-114. https:// doi.org/10.1016/j.marpolbul.2015.12.035

Morales Díaz, M., Corrales Alonso, S., Vanterpoll Héctor, M., Avalos Rodríguez, R., Salabert Tortolo, I. and Hernández Diaz, O. (2018). Cáncer gástrico: algunas consideraciones sobre factores de riesgo y Helicobacter pylori. Revista Médica Electrónica, 40 (2), 433-444. [In Spanish]. https:// doi.org/10.1186/1678-9199-20-51

Mousavi, S. and Dehkordi, F.S. (2014). Virulence factors and antibiotic resistance of Helicobacter pylori isolated from raw milk and unpasteurized dairy products in Iran. Journal of Venomous Animals and Toxins including Tropical Diseases, 20, 51. https://doi.org/10.1186/1678-9199-20-51

Ng, C.G., Loke, M.F., Goh, K.L., Vadivelu, J. and Ho, B. (2017). Biofilm formation enhances Helicobacter pylori survivability in vegetables. Food Microbiology, 62, 68-76. https://doi.org/10.1016/ j.fm.2016.10.010

Olea, A., Díaz, J., Fuentes, R., Vaquero, A. and García, M. (2012). Foodborne disease outbreaks surveillance in Chile. Revista chilena de infectologia, 29(5), 504-510. https:// doi.org/10.4067/S0716-10182012000600004

OMS (2007). Manual sobre las cinco claves para la inocuidad de los alimentos. Retrieved from website: https:/www.who.int/foodsafety/publications/ consumer/manual_keys_es.pdf

OMS (2016). Cinco claves para una mayor inocuidad de los productos de acuicultura con objeto de proteger la salud pública. Organización Mundial de la Salud 
(OMS). Retrieved from website: https:// apps.who.int/iris/bitstream/ handle/10665/251672/9789243510316-spa.pdf? sequence $=1: / /$ www.who.int/foodsafety/ publications $/ 5 \mathrm{keysmanual} / \mathrm{es} /$

Orta de Velásquez, M.T., Yáñez Noguez, I., Casasola Rodríguez, B. and Román Román, P.I. (2016). Effects of ozone and chlorine disinfection on VBNC Helicobacter pylori by molecular techniques and FESEM images. Environmental Technology, 38(6), 744-753.

https:// doi.org/10.1080/09593330.2016.1210680

Otero, R. (2017). Helicobacter pylori in drinking water Is it the route of infection? Acta Médica Colombiana, 42(2), 87-89.

Palomino Camargo, C. and Tomé Boschian, E. (2012). Role of water and foods in Helicobacter pylori transmission. Anales Venezolanos de Nutrición, 25 (2), 85-93.

Palomino-Camargo, C. and González-Muñoz, Y. (2014). Molecular techniques for detection and identification of pathogens in food: advantages and limitations. Revista Peruana de Medicina Experimental y Salud Pública, 31, 535-546. https://doi.org/10.17843/ rpmesp.2014.313.93

Paniagua-Contreras, G L., Monroy-Pérez, E., AlcántaraCarmona, M.L., García-González, O.P. and VacaPacheco, S. (2007). Prevalence of Helicobacter pylori and the vacA y cagA genotypes in saliva of patients with gastritis. Revista Médica del Hospital General de México, 70(3), 107-114.

Pascual Anderson, M.D.R. and Calderon y Pascual, V. (2000). Microbiología alimentaria metodología analítica para alimentos y bebidas. $2^{\text {nd }}$ ed., p. 441. Spain: Ediciones Díaz de Santos. [In Spanish].

Percival, S.L. and Thomas, J.G. (2009). Transmission of Helicobacter pylori and the role of water and biofilms. Journal of Water and Health, 7(3), 469477. https://doi.org/10.2166/wh.2009.070

Pina-Pérez, M.C., González, A., Moreno, Y. and Ferrús, M.A. (2019). Helicobacter Pylori Detection in Shellfish: A Real-Time Quantitative Polymerase Chain Reaction Approach. Foodborne Pathogens and Disease, 16(2), 137-143. https:// doi.org/10.1089/fpd.2018.2495

Posse, R.S.A., Toledo, R.A. and Cabral, M.L.V. (2006). Helicobacter pylori: Clínica, diagnóstico $\mathrm{y}$ tratamiento. Revista de posgrado de la vía catedra de medicina, 158, 9-12. [In Spanish]. http:// medsol.co/informacion/esomed/Helicobacter.pdf

Puig Peña, Y., Espino Hernández, M. and Leyva Castillo, V. (2011). Resistencia antimicrobiana en
Salmonella y E. coli aisladas de alimentos: revisión de la literatura. Panorama. Cuba y Salud, 6(1), 3038. [In Spanish]. https://doi.org/10.1590/S102049892011001200011

Puig Peña, Y., Leyva Castillo, V., Aportela López, N., Camejo Jardines, A. and Tejedor Areas, R. (2019). Antimicrobial resistance in bacteria isolated in fish and shellfish. Revista Habanera de Ciencias Médicas, 18(3), 500-512.

Quaglia, N.C. and Dambrosio, A. (2018). Helicobacter pylori: A foodborne pathogen? World Journal of Gastroenterology, 24(31), 3472-3487. https:// doi.org/10.3748/wjg.v24.i31.3472

Quijada, J., Lima dos Santos, C.A. and Avdalov, N. (2005). Enfermedades parasitarias por consumo de pescado. Incidencia en América Latina. Infopesca Internacional, 24, 16-23. [In Spanish].

Ramírez Ramos, A. and Sánchez Sánchez, R. (2008). Helicobacter pylori and gastric cáncer. Revista de Gastroenterología del Perú, 28(3), 258-66. [In Spanish].

Ramírez, L.C.C., Ospina, M.A.Á., Fonseca, L.A.C. and Beltran, Y.C.C. (2011). Bacteriological quality of fresh fish, Catfish (Pseudoplatystoma sp.) and Red Tilapia (Oreochromis sp.), as marketed in the municipality of El Colegio, Cundinamarca (Colombia). Nova, 9(16), 149-157. https:// doi.org/10.22490/24629448.497

Riveros, S.C.H., Quiroga, A., Marín, J.D.M. and Regino, W.O. (2009). Primary resistance to Clarithromycin in Helicobacter pylori Isolates. Revista Colombiana de Gastroenterología, 24(2), 110-114.

Romero Cabello, R. (2007). Microbiologia y parasitologia humana/Microbiology and Human Parasitology: Bases etiologicas de las enfermedades infecciosas y parasitarias/Etiological Basis of Infectious and Parasitic Diseases. $3^{\text {rd }}$ ed. Mexico: Editorial Médica Panamericana.

Romero-Jarero, J.M. and Negrete-Redondo, M.D.P. (2011). Presence of Gram negative bacteria in fish muscle of commercial importance in the Mexican Caribbean zone. Revista Mexicana de Biodiversidad, 82(2), 599-606. https://doi.org/10.22201/ ib.20078706e.2011.2.465

Saeidi, E. and Sheikhshahrokh, A. (2016). VacA genotype status of Helicobacter pylori isolated from foods with animal origin. BioMed Research International, 2016, 8701067. https:// doi.org/10.1155/2016/8701067

Sanabria Sánchez, G. and Chiquillo Pompeyo, J. (2019). Microbiological analysis of two samples of fish commercialized in Tunja, Boyacá. Case 
study. Cultura Científica, 17, 52-65. https:// doi.org/10.38017/1657463X.594

Sánchez-B, P., Muñoz-M. R. and Gutiérrez-M, N.P. (2012). Bacterial Resistance to Antibiotics: Mechanisms of Transfer. Revista Spei Domus, 8, 3137. https://revistas.ucc.edu.co/index.php/sp/article/ view/94/95

Shahi, S.S. and Yan, G.H. (2018). Contaminated water as a route of Helicobacter pylori transmission: review. International Journal of Science Inventions Today, 7(3), 481-488.

Smith, M., Love, D.C., Rochman, C.M. and Neff, R.A. (2018). Microplastics in seafood and the implications for human health. Current Environmental Health Reports, 5(3), 375-386. https://doi.org/10.1007/ s40572-018-0206-z

Soares, K.M.D.P. and Gonçalves, A.A. (2012). Qualidade e segurança do pescado. Revista do Instituto Adolfo Lutz (Impresso), 71(1), 1-10. [In Spanish].

Soto Varela, Z., Pérez Lavalle, L. and Estrada Alvarado, D. (2016). Bacteria causing of foodborne diseases: an overview at Colombia. Revista Salud Uninorte, 32(1), 105-122. https://doi.org/10.14482/ sun.32.1.8598

Tafur, J.D., Torres, J.A. and Villegas, M.V. (2008). Mechanisms of antibiotic resistance in Gram negative bacteria. Infectio, 12(3), 217-226.

Torrens, H.R., Argilagos, G.B., Cabrera, M.S., Valdés, J.B., Sáez, S.M. and Viera, G.G. (2015). The foodborne diseases, a health problem inherited and increased in the new millennium. Revista Electrónica de Veterinaria, 16(8), 1-27.

van Duynhoven, Y.T.H.P. and Jonge, R.D. (2001). Transmission of Helicobacter pylori: a role for food? Bulletin of the World Health Organization, 79, 455460.

WHO. (2020). Health topics. Foodborne diseases. Retrieved from World Health Organization (WHO) website: https://www.who.int/health-topics/ foodborne-diseases\#tab=tab 1

Yahaghi, E., Khamesipour, F., Mashayekhi, F., Safarpoor Dehkordi, F., Sakhaei, M.H., Masoudimanesh, M. and Khameneie, M.K. (2014). Helicobacter pylori in vegetables and salads: genotyping and antimicrobial resistance properties. BioMed Research International, 2014, 757941. https://doi.org/10.1155/2014/757941

Yu, H.Y., Zhang, B.Z., Giesy, J.P. and Zeng, E.Y. (2011). Persistent halogenated compounds in aquaculture environments of South China: Implications for global consumers' health risk via fish consumption. Environment International, 37(7), 1190-1195.

https://doi.org/10.1016/ j.envint.2011.04.012

Zamani, M., Vahedi, A., Maghdouri, Z. and ShokriShirvani, J. (2017). Role of food in environmental transmission of Helicobacter pylori. Caspian Journal of Internal Medicine, 8(3), 146-152. DOI: 10.22088/cjim.8.3.146 